\title{
STRATEGY TO IMPROVE LABOR PRODUCTIVITY IN PT FREEPOT INDONESIA'S UNDERGROUND MINING PROJECT
}

\author{
Inzi Almuntadzar*), M. Syamsul Maarif*), and Lukman M. Baga**) \\ *) School of Business, IPB University \\ Jl. Pajajaran Bogor 16151, Indonesia \\ **) Department of Agribusiness, Faculty of Economics and Management, IPB University \\ Jl. Agatis, IPB Dramaga Campus Bogor 16680, Indonesia
}

\begin{abstract}
Poor productivity of labor construction causes project cost to increase and project completion schedule behind target. Underground mining company such as PT Freeport Indonesia (PTFI) struggle to overcome problem with productivity. It is critical for mining underground company to keep up labor productivity due to importance of mining production. Therefore, the purpose of this research are: (1) to identify the factors that influence labor productivity; (2) to formulate alternative strategies to increase the productivity; and (3) to formulate recommendations carried out by PTFI in order to increase the productivity. This research use literature review and expert discussion to identify factors affecting labor productivity in the construction industry. The analytical Hierarchy Process (AHP) method used to find the best strategies to increase labor productivity. The result of this research showed that the factors that has the most influence is labor management, the most influencing actor is construction management, the most important goal is to improve project management implementation and the best strategy to increase labor productivity is to create a Project Management Office (PMO) system. The recommendation that can be given is that PTFI needs to develop guidelines and programs for PMO system development and apply PMO to all PTFI mining activity.
\end{abstract}

Keywords: Analytical Hierarchy Process (AHP), Labor productivity, Project Management Office (PMO), Strategies, Underground mining

\begin{abstract}
Abstrak: Produktivitas pekerja konstruksi yang buruk menyebabkan biaya proyek bertambah dan jadwal proyek tertinggal. Perusahaan tambang bawah tanah seperti PT Freeport Indonesia (PTFI) kesulitan untuk memperbaiki masalah produktivitas tersebut. Sangat kritis bagi perusahaan untuk menjaga produktivitas karena berkaitan dengan produksi tambang. Oleh karena itu, penelitian ini bertujuan (1) mengidentifikasi faktor - faktor yang berpengaruh terhadap produktivitas pekerja; (2) merumuskan strategi peningkatan produktivitas pekerja; dan (3) merumuskan rekomendasi bagi PTFI untuk meningkatkan produktivitas pekerja. Penelitian ini menggunakan metode ulasan literatur dan diskusi pakar untuk mencari faktor pengaruh produktivitas pekerja. Metode Analytical Hierarchy Process (AHP) digunakan untuk mencari strategi terbaik untuk meningkatkan produktivitas pekerja. Hasil penelitian menyatakan bahwa faktor yang paling memengaruhi produktivitas pekerja adalah pengelolaan pekerja, aktor paling memengaruhi adalah manajemen konstruksi, tujuan paling utama agar produktivitas pekerja meningkat adalah meningkatkan implementasi manajemen proyek dan strategi terbaik untuk meningkatkan produktivitas pekerja adalah membuat sistem Project Management Office (PMO) dalam pelaksanaan proyek konstruksi tambang bawah tanah. Saran yang direkomendasikan adalah PTFI perlu membuat pedoman dan program untuk pengembangan sistem PMO dan menerapkan PMO di semua kegiatan operasional tambang PTFI.
\end{abstract}

Kata kunci: Analytical Hierarchy Process (AHP), Produktivitas pekerja, Project Management Office (PMO), Strategi, Tambang bawah tanah

${ }^{1}$ Alamat korespondensi:

Email: ialmunta@fmi.com 


\section{INTRODUCTION}

Labor productivity has become an often-discussed topic in the construction industry since it affects the costs and schedule of construction projects. Construction companies aim to keep great labor productivity so that company profits are not affected. Not only that, it can also affect the economy of the nation (Naoum, 2016; Durdyev et al. 2018; Alaghbari et al. 2019). According to Central Statistics Agency (BPS), the construction industry sector contributes approximately $10 \%$ of Indonesia's Gross Domestic Product (GDP) so it is important for stakeholders who are involved to maintain labor productivity in order to continue giving contribution to the company and the state.

The importance of labor productivity to construction projects forces construction companies to take measurements to keep an effective labor productivity. Before the measurements are made, it is important for companies to know how productivity is defined. In general, the definition of productivity is the ratio between input and output. This comparison model can be used according to the orientation applied such as economy, construction, and activity (Thomas et al. 1990). In this study, the definition of productivity is the ratio between earned manhours and actual manhours (Reid, 1999). Earned manhours are the sum of labor manhours earned according to the physical achievement of progress. Actual manhours are the sum of labor manhours spend to achieve progress. A measurement that uses working hours provides flexibility and usually suitable for the construction industry since there are various activities involved. The difficulty of measuring CLP using working hours is usually caused by a different perspective in terms of progress achievement. That is why, it is important to clarify before conduct measurement.

As one of the largest coppers and gold mining companies in the world, PT Freeport Indonesia (PTFI) currently expand their underground mining after the surface mining is closed. The expansion project requires capital expenditure with a total project cost of US \$ 861 million dollars. This project involves a large number of workers, so PTFI measures labor productivity as part of supervision and control. Labor productivity report shows that around $63 \%$ of the total underground mining projects are experiencing a decrease in labor productivity. Poor productivity has led to project cost overruns and causes the project schedule to slip. Abdel-
Hamid et al. (2020) stated that $18 \%$ of time and cost loss happens due to poor productivity. PTFI policy stated that cost variance that exceeds $15 \%$ of the direct cost will require a supplemental budget, and that is not good for the company cashflow.

Previous studies that discussed labor productivity was carried out by most researchers by looking for factors that influence labor productivity. This research produces influencing factors for labor productivity such as worker ability (Muqeem et al. 2011; El-Gohary and Aziz, 2014; Naoum, 2016; Chaturvedi et al. 2018; Alaghbari et al. 2019; Hamza et al. 2019), material management (Kaming et al. 1997; Makulsawatudom et al. 2004; Kadir et al. 2005; Enshassi et al. 2007), and project planning (Naoum, 2016; Hamza et al. 2019; Doloi, 2008).

However, studies that discussed strategies in increasing productivity are very limited. Research from Ghodrati et al. (2018) shows that management strategies such as communication, incentives, and worker management have an effect on labor productivity. However, strategies such as training, supervision and work methods have shown no effect which is contradictory to what Koch and McGrath (1996) has stated. The study stated that companies that systematically train and develop their workers are more likely to enjoy rewards in the form of a more productive workforce than those that don't.

On the other hand, discussion and research on determining factors and strategies to increase labor productivity may be found, but researches that address mining productivity are very rare. Only a few studies have discussed it such as research by Garcia et al. (2000); Joaquín et al. (2010) and de Solminihac et al. (2018). There are several reasons why this research is difficult to find: 1 . Limited data access. Mining company policies limit the release of internal company data; 2 . Limited underground mining area. Not all countries have underground mines, so researches are limited only to countries that have underground mining areas; 3 . Low research interest. Research in underground mining areas requires strict permissions and costs a lot, which discourages researchers from choosing the topic.

The author saw that there are gaps after knowing the importance of labor productivity for construction projects, seeing the decreasing productivity data of PTFI workers which could potentially cause losses, and the lack of previous research. Therefore, the author 
learned that there should be a research that discusses labor productivity in underground mining areas. Hence, the purpose of this study is to identify the factors that mostly influence the productivity of underground mining project labor, formulate alternative strategies, and provide recommendations for PTFI to increase labor productivity.

\section{METHODS}

This research was conducted at the PT Freeport Indonesia mine in the underground mining area, Tembagapura, Mimika Regency, Papua Province from November 2019 to October 2020. The preparation for this research included collecting previous research information, research supporting data, taking survey data, interviewing the expert, data processing, writing and research consulting. This research uses quantitative and qualitative approaches. The quantitative approach is carried out by survey methods using a questionnaire as an instrument for collecting research data. A qualitative approach is carried out through in-depth interviews with respondents to gather information about the variables researched. This research used primary and secondary data as research materials. Primary data for this study were collected through in-depth interviews on construction expert who has 10 years of experience or holds the management positions. Meanwhile, secondary data were obtained from a review of previous research literature and a review of statistical data from the Central Statistics Agency (BPS).

The research started by conducting a literature review to find out information about the factors that influence the productivity of construction labor. Literature review plays an important role as a foundation for research, serves as a basis for knowledge development, establishes guidelines for policy and practice, provides evidence of the effect that, if done well, has the capacity to generate new ideas and directions for a particular field (Snyder, 2019). Therefore, by reviewing the literature, the authors have insight about influencing factors so the interviews with experts become more focused and on target. The influence factor then discussed with experts to find out what factors are relevant to the research. In-depth interviews with 5 construction experts, who has 10 years of experience and holds the management positions, are expected to help assess and determine the critical factors based on knowledge and expertise in construction.
After getting the factors that are considered relevant, the next step was to formulate a strategy to increase labor productivity using the AHP method. The AHP method uses the principle of hierarchical composition to obtain alternative priorities by referring to the priority of several criteria. The AHP method can measure physical and social sizes as well as provide comprehensive solutions to a problem, both intuitively, rationally, and simultaneously. This method also provides easy and complex solutions simultaneously in the sense that it can handle complex real problems (Saaty, 1986; Saaty, 1987).

In the AHP, the first step was to define the problem and determine the focus or the goal. In this study, the focus or goal the author want to achieved is to choose a strategy for improvement to increase labor productivity. Therefore, the box belong to improvement strategy is placed at the top of the hierarchy. The second step was to create a hierarchical structure starting from the top level, namely the focus or goal to be achieved. The second level is the factors that affect labor productivity. After these factors, the hierarchy is passed down to the actors. Actors will contain parties who are considered to influence the focus and factors. The third level is the goals to achieved and the bottom level is alternatif strategies to increase labor productivity. The third step was to make a pairwise comparison. Descriptive analysis was carried out to explain the factors, actors, goals and strategy improvements that are most influential for the Central Service Division as a construction project implementer in dealing with labor productivity problems and to analyze the managerial implications for PTFI. In general, the research framework can be seen in Figure 1

\section{RESULT}

\section{Identification of Relevant Influence Factors}

Some relevant labor productivity influence factors based on the results of previous research reviews as well as the discussion with construction expert sources resulted in 5 influencing factors. The selection of these factors was made after considering the different work locations in general, which in this case is the underground mine. Therefore, the consideration of problems often arises in labor productivity which is often faced by experts when they are carrying out the project in the underground mining areas. These factors are: 
1. Material. The availability and quality of materials considered by experts can increase labor productivity (Alaghbari et al. 2019; and El-Gohary and Aziz, 2014).

2. Labor management. Labor management activities include but are not limited to supervision of labor (Enshassi et al. 2007; Hickson and Ellis, 2014; Hughes and Thorpe, 2014; Durdyev et al. 2018; Hamza et al. 2019), management of conflicts among labor, skills, and knowledge development of labor (Naoum 2016; Hamza et al. 2019; Chaturvedi et al. 2018; Robles et al. 2014; Alaghbari et al. 2019; Muqeem et al. 2011).

3. Project planning. This includes activities such as preparing a schedule of activities, obtaining materials and equipment, preparing labor allocations, engineering, and administration. The more time allocated to the planning process, the more likely to achieve the project target (Dvir and Lechler, 2004; Armstrong, 1982; Urbański et al. 2019)

4. Communication and coordination. Through an effective communication style, work activities can be efficiently assigned, implemented and supervised (Solaja et al. 2016).

5. UG (underground) work area. Usukhbayar and Choi (2018) stated that work location and weather conditions can affect labor productivity.

\section{Hierarchy Structure of Analytical Hierarchy Process (AHP)}

The determination of AHP structure was done by breaking the problem into several parts in a systematic way. After obtaining the relevant influence factors, the researcher then divided the problem into a hierarchical structure that has several levels. The first level is the focus on increasing labor productivity. The second level is the influence factor based on the results of discussions with experts. The third level is the actor that shows labor productivity. The selection of actors was based on the criteria of responsibility and their role in project implementation. The fourth level is the goal that must be achieved to increase the labor productivity. The fifth level is a strategy to increase labor productivity. This strategy was made by referring to the whole hierarchy above it. The AHP hierarchical form was determined through literature reviews and discussions with experts. The structure describes the whole process and some problems arise based on historical data. Overall, the AHP hierarchical structure of this study can be seen in Figure 2.

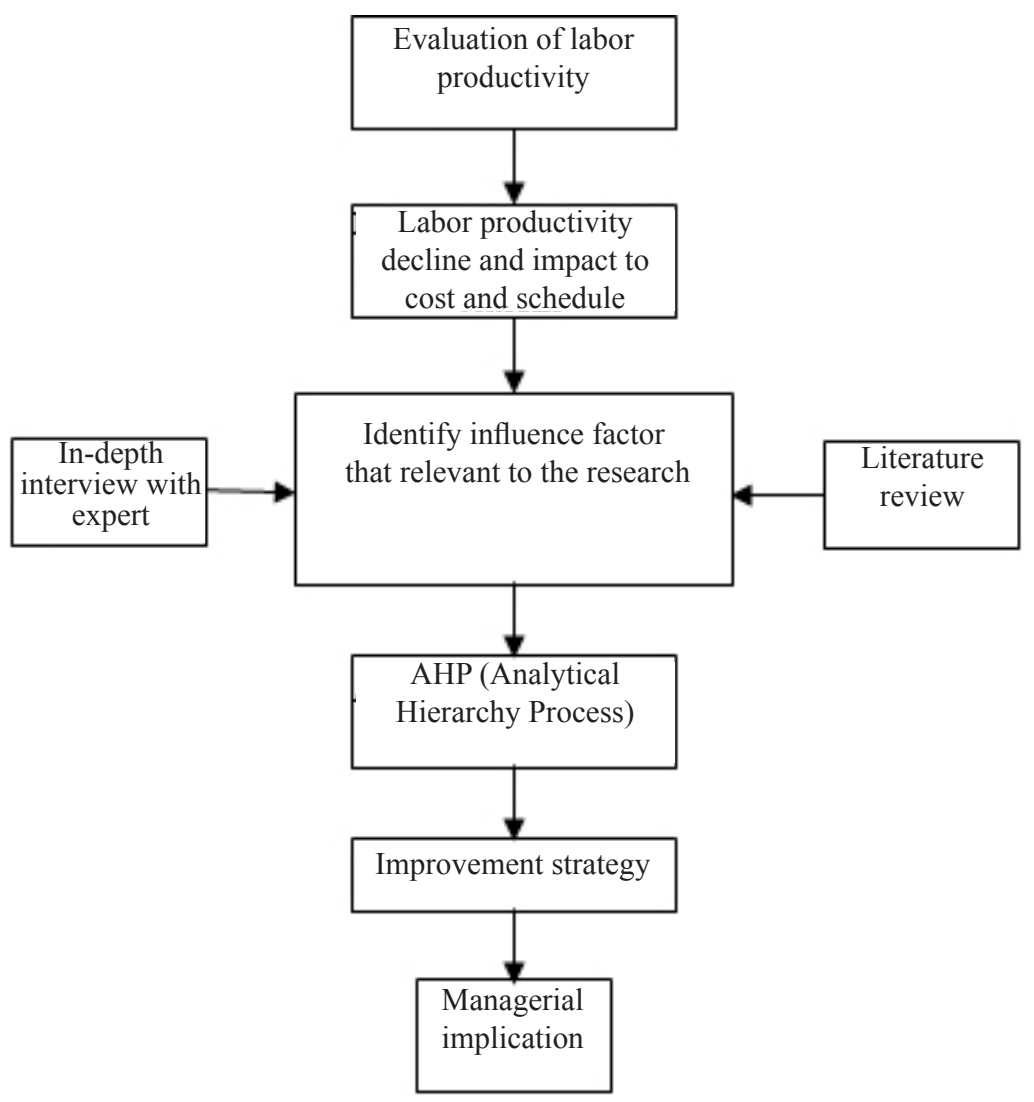

Figure 1. Research framework 


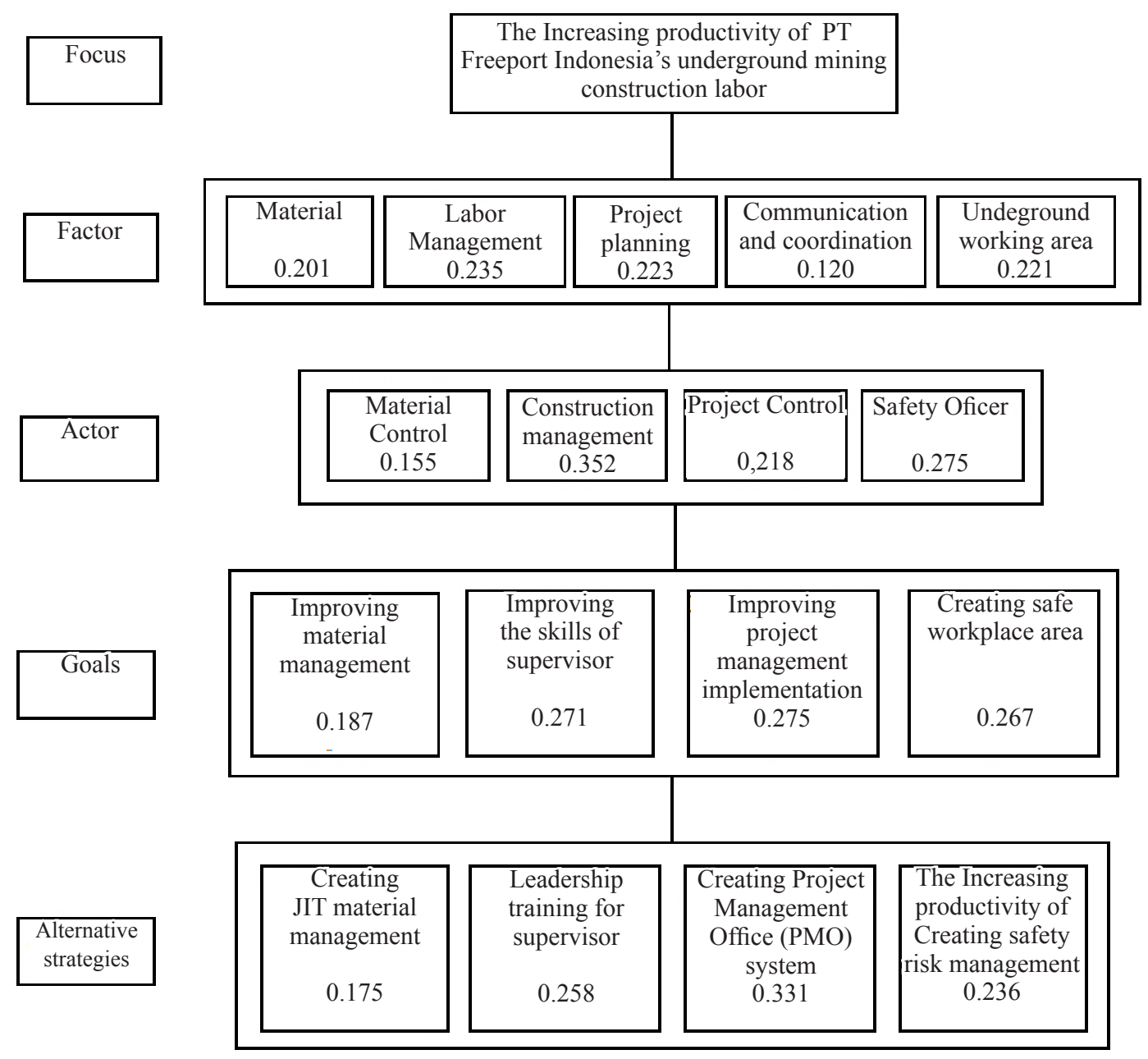

Figure 2. AHP hierarchical structure

\section{The Effect of Factors on Focus}

Thisresearchsurveywasconductedonsevenconstruction experts which include one Senior Construction Manager, three Construction Superintendents and three supervisor levels. The analysis found that the CI (Consistency Index) value was 0.03 or $<0.1$ which indicated that the assessment was acceptable. Based on the results of the AHP analysis calculation, the influence factor on focus is shown in Table 1. The judgement of construction experts on the influence factor put the labor management factor as the factor that influence labor productivity the most. Previous research from Gurmu and Ongkowijoyo (2020) showed that clear delegation of responsibilities, a stable organizational structure, and crew composition are some parts of Human Resources Management (HRM) practices that affect labor productivity. Based on the discussion with experts, crew composition can affect worker productivity. Unbalanced workforce abilities in a crew may lead to a decreased productivity along with a big age gap that can affect worker productivity.

Management of workers that is often carried out by companies is by doing performance management to ensure that workers have met the expectations and targets set by the organization (Bacal, 2002). The practice of performance management that is often carried out in companies is by conducting performance appraisals. The employee assessment carried out at PTFI includes 4 Key Result Areas (KRA), such as safety, collaboration, empowerment, and work areas. Based on the observation, this performance appraisal process encourages workers to achieve KRA targets and has an effect on increasing worker productivity. When workers achieve more KRA targets and more satisfied with the performance appraisal system, their productivity will also increase (Gruman and Saks, 2011). 
Table 1. Influence of factor to focus

\begin{tabular}{lc}
\hline Factor & Weighted \\
\hline Labor management & 0.235 \\
Project planning & 0.223 \\
Underground working area & 0.221 \\
Material & 0.201 \\
Communication and coordination & 0.120 \\
\hline
\end{tabular}

Project planning was the second factor affecting labor productivity. According to Doloi (2008) the elements of human resource planning, work scheduling, activity programming, and location coordination planning must be the initial focus of construction organizations if the company want to increase labor productivity. In his research, Doloi stated that these elements fall into the category of project planning (work planning). This indicated that the relationship between activity planning and the main factors in labor management was interrelated. Doloi considered that labor management is part of activity or work planning. According to the existing conditions, in the past, activity programming was carried out using the Primavera project planning software. The Primavera preparation work schedule includes the loading of labor, which will be used by the construction team for workforce allocation. Construction experts think that the lack of workforce allocation will have an impact on labor productivity.

The underground area has high safety risks such as hanging rock, wet muck, and toxic gas. These risk potentially occurs in the middle of the project phase and it will give an impact on productivity. But from expert judgment, the work area factor only occupies the third position under performance management and activity planning. This can be explained for reason the safety and health of PT Freeport Indonesia's underground mining work areas have been very well-handled so these factors do not significantly affect labor productivity.

Previous research that discussed work area as an effect of productivity was carried out by Ibbs and Sun (2017) and Usukhbayar and Choi (2018). The research does not directly address the work area as an influence factor, but discusses the extreme weather and climate that is often found in underground mines. According to Usukhbayar and Choi (2018), strong winds and rainfall affect worker productivity. Both of these can be found at PTFI underground mining sites and the strong wind in the underground mine came from the Main Fan in the underground mining tunnel.
Material factors was the next influencing factors that can affect labor productivity. Experts considered the material as a factor since it is related to project activities. The availability, the quality and the delivery of material are important things that can affect labor productivity in the field. This is in line with the statement of Thomas et al. (1989) that investing in material management such as storage, accelerating and sequencing the delivery of materials can give an impact on productivity.

The last factor was communication and coordination. According to Riel and Fombrun (2007) in their book Essential of Corporate Communication, communication described as a blood in an organization, knowing as a medium for organizational resources. It is through communication that an organization can access resources such as labor, materials, equipment and others. Without communication, it is impossible for the organization to operate. According to Roberts and O'Reilly (1979), workers who are connected through communication tend to have a higher work performance compared to those who are isolated from communication.

\section{The Effect of Actors on Focus}

Based on the judgement of the expert, Table 2 shows the rank of the actor influence on focus. The actor that mostly influences the focus on increasing the productivity of underground mining workers is construction management. The role of a construction management can be seen in a project manager. Project managers have the authority to regulate and direct the process of a project. Experts viewed this strategic position as having a role in increasing worker productivity. The project manager also responsible for most of the factors affecting labor productivity such as labor management, activity planning, communication and coordination, as well as materials. Therefore, the role of actors in construction management is very important in increasing labor productivity. This is in line with Lee et al. (2015) and Kusumawati et al. (2019) who stated that a project manager can increase labor productivity by controlling the influence factors in the construction phase. A manager must also pay attention to things such as discipline and the ability of workers to increase productivity. Meanwhile, Kerzner (2009) stated that to be more efficient as a project manager, one must have management and technical skills. So, it is very important for organizations to choose the right project manager. When project requirements and project manager competencies are considered, the project will 
be assigned to a project manager who is competent and can respond to a set of project requirements. Such assignments should lead directly to project success (Patanakul, 2011).

The next actor who affected worker productivity was the safety officer. The safety officer has a duty to ensure that safety and health procedures in the PTFI work environment are carried out. The role of the safety officer in productivity is to provide a sense of security and safety to workers during the implementation of construction activities. In the process of doing so, the safety officer actor will depend on the project manager. The project manager as project coordinator, has the authority to supervise the safety officer.

Project control are actors in the third rank that affects worker productivity. This was the result of expert judgment because project control plays a role in the activity of planning process. Discussions with experts stated that project control actors have a strategic role in project implementation. Apart from playing a role in project planning, project control act as a team that manage productivity, project schedule and project costs. Project control can provide feedback to the project manager on labor productivity during the project. This feedback can be used by the project manager to make improvements to the construction process in order to increase labor productivity.

The final actor is the material control team. The material control team is a group that responsible for managing project materials. According to experts, material control actors have a fairly large role in increasing labor productivity. This was related to the provision of project materials to be installed in the field. The consistent supply of materials ensures that field activities continue so that work targets can be achieved. The achievement of job targets will directly affect labor productivity.

\section{The Effect of Goals on Focus}

The most important goal to increase labor productivity according to experts was improving the implementation of project management (Table 3). According to the Project Management Institute (2007), project management includes the application of knowledge, skills, tools and techniques for project activities to achieve project goals. Project management was achieved through the appropriate application and integration of identified management processes for the project. Its role enabled the organization to carry out projects effectively and efficiently. This is considered by experts to increase worker productivity. This opinion is supported by Al-Hajj (2018) which stated that the success of a project depends on the training of practitioners, the achievement of time and level of project management implementation, while the human factor plays an important part in achieving project success. Meanwhile, the role of project management to increase worker productivity is related to the main influence factors, such as worker management (Agrawal, 2019) and activity planning.

The next goal after project management was to improve the skill of supervisors as an effort to increase labor productivity. The main role of the supervisor is to supervise the field activities to run smoothly and achieve project targets. This supervisory function is important for project workers in order to achieve the planned productivity. The productivity of unattended workers tend to decrease, while workers with supervision have high productivity. This was in line with Jimoh et al. (2017) that looked further at monitoring problems in communication, experience and commitment, inadequate record documentation, and lack of motivation and unclear instructions.

The next goal to increase labor productivity was to create a safe and secure workplace. According to the opinion of experts, workplace safety and security could affect the psychological factors of workers. If the workplace is safe and secure, workers will feel comfortable and that will increase their productivity. This was in line with Sudwiyatmoko et al. (2014) which stated that safety has a significant effect on productivity. Furthermore, Lee et al. (2020) stated that the climate of the workplace affects labor productivity. The final objective was to improve the project material management in terms of quality and delivery time. The quality of project materials that appropriate with the specifications of the plan can increase the success of installing these materials in the field. If the quality of the material is not suitable, it requires rework or repair so the material can be installed.

Table 2. Influence of actor to focus

\begin{tabular}{lc}
\hline Actor & Weighted \\
\hline Construction management & 0.352 \\
Safety officer & 0.275 \\
Project control & 0.218 \\
Material control & 0.155 \\
\hline
\end{tabular}




\section{Alternative strategies to increase worker productivity}

Based on the opinion of experts, the strategy to increase the productivity of PTFI's underground mine workers showsthat thestrategyofmakingtheProjectManagement Office (PMO) system in project management is the most important strategy (Table 4). According to PMI (2017) PMO is an organizational structure that standardizes project-related governance processes and facilitates the sharing of resources, methodologies, tools and techniques. The responsibilities of PMO can range from providing support functions for project management to direct management of one or more projects. The functions of PMO include managing and conducting project resources, providing and developing methods, best practices and work standards, coaching, training, developing and managing project policies, procedures, templates, and other joint documentation (organization processing assets); and the coordination of cross-project communication (PMI, 2017).

By using PMO, work planning, communication, and coordination in the PTFI became more focused and direct. Activity planning requires input from all stakeholders involved. One important thing that is currently overlooked is the intellectual property of project management. Even during this time, there is no lesson learned system for projects that have been undertaken by the PTFI. This knowledge is still in a form of scattered tacit (implicit) knowledge. With the help of PMO, this knowledge can be converted into explicit knowledge which can provide input to project planning. Not only lessons learned, PMO also regulates risk management, earn value management, and change management that can provide input to the project planning process. The PMO also manages communication and project coordination. Through PMO, a Project Dashboard will be created that contains all of the information about the project. This information system can improve communication and coordination between functional project teams, so it can increase worker productivity. Overall PMO can ascertain whether the implementation of project management is carried out correctly which can directly improve performance or productivity (Dai and Wells 2004). In addition, PMO can also reduce the risk of uncertainty in working on construction projects and increase performance or productivity (Liu and Yetton, 2007).
The second strategy with a score of 0.258 is referring to the leadership training for supervisors. This strategy was carried out because supervisors are the front line of management in the implementation of construction projects. Supervisors know the needs of the project, especially in terms of managing materials, equipment and most importantly managing workers. The leadership training strategy is carried out so that supervisors are able to manage project resources so that productivity increases (El-Gohary and Aziz, 2014; Naoum, 2016).

The third strategy is a strategy in making safety risk management with a value of 0.237 . Safety risk management includes activities to ensure the safety and health of workers are protected. These activities include carrying out 5 steps to safety, Master Observation, and Fatal Risk Management (FRM). 5 steps to safety are activities that must be performed by workers before carried out the work.

The last strategy is to create a JIT (Just in Time) material management system. Material management is the last strategy that requires proper coordination with all parties involved in projects and other divisions such as Supply Chain Management (SCM). The JIT-based material management strategy in the construction industry is still very limited in application and very lagging behind compared to the manufacturing industry (Akintoye, 1995). According to Seng et al. (2018) the processes of an effective material supply chain are critical to the success of any construction project and are the determining factor between a successful project with a project fraught with delays and claims.

Table 3. Influence of objective to focus

\begin{tabular}{lc}
\hline Objective & Weighted \\
\hline Improving project management & 0.275 \\
implementation & \\
Improving the skills of supervisor & 0.271 \\
Creating safe workplace area & 0.267 \\
Improving material management & 0.187 \\
\hline
\end{tabular}

Table 4. Alternative strategy improvement

\begin{tabular}{lc}
\hline Strategy & Weighted \\
\hline Creating Project Management Office (PMO) & 0.331 \\
system & \\
Leadership training for supervisor & 0.258 \\
Creating safety risk management & 0.236 \\
Creating JIT material management & 0.175 \\
\hline
\end{tabular}


A recommendation that can be given to PTFI by looking at the influence factors and the strategy for improvement is that PTFI must pay attention to policies related to human resource development. Policies must pay attention to the necessary needs without neglecting safety and health of their worker.

\section{Managerial Implications}

PT Freeport Indonesia must establish a project management Standard Operating Procedure (SOP) for project management, improve skills and knowledge, improve communication and coordination, create knowledge management, create risk management, apply Earn Value Management, create change management system, create project management system, and evaluate safety and health risk management in the field. Meanwhile, the recommendation that can be given is that PTFI needs to develop guidelines and programs for PMO system development and apply PMO to all PTFI activity. This implication has a direct transformation to the project execution and the PTFI organization. The transformation include the increase use of project management information system such as reporting system, project status information data, and project dashboard. Information system plays an important role to the organization and the success of project goal. Furthermore, knowledge will flourish in the PTFI organization so the organization will change into knowledge organization.

\section{CONCLUSIONS AND RECOMMENDATIONS}

\section{Conclusions}

The results of the study lead to a conclusion that the factor that mostly influences the productivity of PT Freeport Indonesia's underground mining project is labor management. The most influencing actor is the construction management, and the most important goal to increase labor productivity is to improve project management implementation. Meanwhile, the main strategy is to create a Project Management Office (PMO) system for the implementation of PTFI projects. PMO is necessary for effective and efficient management of project resources and ensuring that project management is being implemented.

\section{Recommendations}

Based on the results and the conclusions, the recommendation that can be given is that PT Freeport Indonesia needs to develop guidelines and programs for PMO system development. The recommendation also include apply PMO to all PTFI activities including maintenance and operation. Future research can be done on other activities including maintenance and operation of PTFI to see whether different strategies can be obtained.

\section{REFERENCES}

Abdel-Hamid M, Abdelhaleem HM. 2020. Impact of poor labor productivity on construction project cost. International Journal of Construction Management. 2020:1-8.

Kadir MR, Lee WP, Jaafar MS, Sapuan SM, Ali AAA. 2005. Factors affecting construction labour productivity for Malaysian residential projects. Structural Survey. 23(1):42-54.

Agrawal A, Halder S. 2019. Identifying factors affecting construction labour productivity in India and measures to improve productivity. Asian Journal of Civil Engineering 21:569-579.

Akintoye A. 1995. Just-in-Time application and implementation for building material management. Construction Management and Economics 13(2):105-113.

Alaghbari W, Al-Sakkaf AA, Sultan B. 2019. Factors affecting construction labour productivity in Yemen. International Journal of Construction Management 19(2017):79-91.

Al-Hajj A. 2018. The impact of project management implementation on the successful completion of projects in construction. International Journal of Innovation, Management and Technology 9(1):21-27.

Armstrong JS. 1982. The value of formal planning for strategic decisions: Review of empirical research. Strategic Management Journal 3(3):197-211.

Bacal R. 2011. Performance Management. New York: McGraw-Hill Professional.

Chaturvedi S, Thakkar JJ, Shankar R. 2018. Labor productivity in the construction industry: An evaluation framework for causal relationships. Benchmarking 25(1):334-356.

Dai CX, Wells WG. 2004. An exploration of project management office features and their relationship 
to project performance. International Journal of Project Management 22(7):523-532.

de Solminihac H, Gonzales LE, Cerda R. 2018. Copper mining productivity: lessons from Chile. Journal of Policy Modeling 40(1):182-193.

Doloi H. 2008. Application of AHP in improving construction productivity from a management perspective. Construction Management and Economics 26(8):841-854.

Durdyev S, Ismail S, Kandymov N. 2018. Structural equation model of the factors affecting construction labor productivity. Journal of Construction Engineering and Management 144(4):1-11.

Dvir D, Lechler T. 2004. Plans are nothing, changing plans is everything: the impact of changes on project success. Research Policy 33(1):1-15.

El-Gohary KM, Aziz RF. 2014. Factors influencing construction labor productivity in Egypt. Journal of Management in Engineering 30(1):1-9.

Enshassi A, Mohamed S, Mustafa ZA, Mayer PE. 2007. Factors affecting labour productivity in building projects in the Gaza strip. Journal of Civil Engineering and Management 13(4):245254.

Garcia P, Knights PF, Tilton JE. 2000. Measuring labor productivity in mining. Minerals and Energy Raw Materials Report 15(1):31-39.

Ghodrati N, Wing Yiu T, Wilkinson S, Shahbazpour M. 2018. Role of managementstrategiesinimproving labor productivity in general construction projects in New Zealand: Managerial Perspective. Journal of Management in Engineering 34(6):111.

Gruman JA, Saks AM. 2011. Performance management and employee engagement. Human Resource Management Review 21(2):123-136.

Hamza M, Shahid S, bin Hainin MR, Nashwan MS. 2019. Construction labour productivity: review of factors identified. International Journal of Construction Management 1-13.

Hickson BG, Ellis LA. 2014. Factors affecting construction labour productivity in Trinidad and Tobago. The Journal of the Association of Professional Engineers of Trinidad and Tobago 42:4-11.

Hughes R, Thorpe D. 2014. A review of enabling factors in construction industry productivity in an Australian environment. Construction Innovation 14(2):210-228.

Ibbs W, Sun X. 2017. Weather's effect on construction labor productivity. Journal of Legal Affairs and Dispute Resolution in Engineering and Construction 9(2):1-7.

Jimoh R, Oyewobi L, Suleiman S, Isa R. 2017. Influence of supervision on labour productivity on construction sites in Abuja-Nigeria. Independent Journal of Management \& Production 8(1):118.

Joaquín JJ, Pérez P, Villalobos P. 2010. Good deposits are not enough: mining labor productivity analysis in the copper industry in Chile and Peru 1992-2009. Resources Policy 35(4):247-256.

Kaming PF, Olomolaiye PO, Holt GD, Harris FC. 1997. Factors influencing craftsmen's productivity in Indonesia. International Journal of Project Management 15(1):21-30.

Kerzner H. 2009. Project Management: a systems approach to planning, scheduling, and controlling. NEW JERSEY (NJ): John Wiley \& Sons.

Koch MJ, McGrath RG. 1996. Improving labor productivity: human resource management policies do matter. Strategic Management Journal 17(5):335-354.

Kusumawati R, Maarif MS, Nurdiati S. 2019. Strategi peningkatan kinerja karyawan taman buah Mekarsari. Jurnal Aplikasi Bisnis dan Manajemen 5(1):59-70.

Lee B, Lee HS, Park M, Kim H. 2015. Influence factors of learning-curve effect in high-rise building constructions. Journal of Construction Engineering and Management 141(8):1-11.

Lee JS, Son S, Kim S, Son K. 2020. Correlation analysis of safety climate and construction productivity in South Korea. International Journal of Occupational Safety and Ergonomics 1-17.

Liu L, Yetton P. 2007. The contingent effects on project performance of conducting project reviews and deploying project management offices. IEEE Transactions on Engineering Management 54(4):789-799.

Makulsawatudom A, Emsley M, Sinthawanarong K. 2004. Critical factors influencing construction productivity in Thailand. Construction. 14(3):1446-1456.

Muqeem S, Idrus A, Khamidi MF, bin Ahmad J, Zakaria S. 2011. Construction labor production rates modeling using artificial neural network. Electronic Journal of Information Technology in Construction 16(1):713-726.

Naoum SG. 2016. Factors influencing labor productivity 
on construction sites: a state-of-the-art literature review and a survey. International Journal of Productivity and Performance Management 65(3):401-421.

Patanakul P. 2011. Project manager assignment and its impact on multiple project management effectiveness: an empirical study of an it organization. EMJ - Engineering Management Journal 23(4):14-23.

PMI. 2017. Project Management Body of Knowledge. ProjectManagement Institute. PENNSYLVANIA (PA): Project Management Institute, Inc.

Reid AP. 1999. Project Management: Getting It Right. Planning And Cost Manager's Guide. CAMBRIDGE (CB). CRC Press/Woodhead Publishing Ltd.

Riel CB, Fombrun CJ. 2010. Essentials of Corporate Communication: Implementing Practices for Effective Reputation Management. OXON (OX): Routledge.

Roberts KH, O'Reilly CA. 1979. Some correlates of communication roles in organizations. Academy of Management Journal 22(1979):42-57.

Robles G, Stifi A, Ponz-Tienda José L. GS. 2014. Labor productivity in the construction industry -factors influencing the Spanish construction labor productivity. International Journal of Civil, Architectural, Structural and Construction Engineering 8(19):999-1008.

Saaty RW. 1987. The analythical hierarchy process what it is and how it is used. Math Modelling 9(3-5):161-176.

Saaty TL. 1986. Axiomatic foundation of the analytic hierarchy process. Management Science 32(7):841-855.

Seng LY, Riazi SRM, Nawi MNM, Ismail R. 2018. Review of material supply chain management during pre-construction phases in Malaysia. International Journal of Supply Chain Management 7(1):155-162.

Snyder H. 2019. Literature review as a research methodology: an overview and guidelines. Journal of Business Research 104:333-339.

Solaja OM, Idowu FE, James AE. 2016. Exploring the relationship between leadership communication style, personality trait and organizational productivity. Serbian Journal of Management 11(1):99-117.

Sudwiyatmoko M, Rodhiyah R, Nurseto S. 2014. Pengaruh disiplin kerja, keselamatan dan kesehatan kerja, serta lingkungan kerja terhadap produktivitaskaryawanbagianproduksipt.barlow tyrie indonesia. Jurnal Ilmu Administrasi Bisnis 3(4): 122-131.

Thomas HR, Maloney WF, Horner RMW, Smith GR, Handa VK, Sanders SR. 1990. Modeling construction labor productivity. Journal of Construction Engineering and Management 116(4):705-726.

Thomas HR, Sanvido VE, Sanders SR. 1989. Impact of material management on productivity - a case study. Journal of Construction Engineering and Management 115(3):370-384.

Urbański M, Haque AU, Oino I. 2019. The moderating role of risk management in project planning and project success: evidence from construction businesses of Pakistan and the UK. Engineering Management in Production and Services 11(1):23-35.

Usukhbayar R, Choi J. 2018. Determining the impact of key climatic factors on labor productivity in the Mongolian construction industry. Journal of Asian Architecture and Building Engineering 17(1):55-62. 